\title{
"In a Twelfth-century Hand, in Latin, with Abbreviations": The Independent Scholar as a Mirror for the University
}

\section{Claire Fanger}

The Professor was as poor as a church mouse, and he lived by himself in one of the Ridings in what had once been a gamekeeper's cottage....

He was a failure, but he did his best to hide it. One of his failings was that he could scarcely write, except in a twelfth-century hand, in Latin, with abbreviations. Another was that, although his cottage was crammed with books, he seldom had anything to eat. He could not tell from Adam, any more than Maria could, what the latest quotation of Imperial Chemicals was upon the Stock Exchange.

In the daytime, he used to chop wood and cut some slices of bread and butter. In the evenings, having lighted the choppings, he would sit before the fire and quaff a glass of liquor, pondering the remarks of Isidore, Physiologus, Pliny, and similar people. His tipples were Cowslip, Dandelion, Elderberry and sometimes Gooseberry Wine, which he brewed himself. Inflamed by these, in the kind glow of the green ash, he would dream of impossible successes: imagining that the master of Trinity had referred to him by name in a lecture, or that Dr Cook had offered to mention him in a footnote to Zeus, or even that one of the poorer colleges had given him a sort of supernumerary fellowship of the lowest class, carrying a stipend of about five pounds a year, so that he would no longer have to cut his bread and butter (T.H. White, Mistress Masham's Repose). ${ }^{1}$

I have always felt an affinity for the character of the Professor in Mistress Mashain's Repose, though it is ruefully that I have chosen to begin my essay on my development 
as a scholar in Canada with a quotation about failure. However if there are any narratives about independent scholarship that are narratives of success I have not been able to find them. As a consequence, in order to establish any sort of narrative base for my own experience at all, I must choose between a few scattered and mostly unilluminating examples of more or less marginal learned gentlemen. The Professor remains my favorite, though he may be less well known than that other classic narrative about unaffiliated scholarship, Thomas Hardy's Jude the Obscure, which I mostly try not to think about (though I confess there have been off moments when I have felt an affinity for poor Jude as well).

The life of T.H. White's Professor is characterised by a mixture of isolation and exclusion. The isolation is at least partly self-imposed, a natural preference (perhaps familiar to most medievalists) for dead languages over living speech; but partly also the result of a university training (figured by his ability to write only in a twelfthcentury hand, in Latin) which has made him quaintly unfit to live in the modern world. His exclusion, however, is not only from the World; he is excluded also, more painfully though less completely, from the life of the university too. Here he differs from Jude, the autodidact, whose exclusion from the university is more thorough and is there from the beginning. Jude never makes it into Christminster at all, except as a mason; he is allowed to build the walls, but not to penetrate them. Clearly those walls were penetrated by the Professor at one time; indeed he is so thoroughly a product of his university training that he could not even be imagined to exist without it. So much is this true that White never bothers to give him a name; he is referred to throughout the book only by an indexical referent to a university status he does not have: "the Professor." Despite the fact that for him even a fellowship of the lowest class is an "impossible dream," he remains "the Professor" because it is not possible for him to be anything else. He is not just a failure; he is also a little microcosm of the university that has spun off from its dynamic centre and attained a separate existence. His cottage life is that of the macrocosmic university writ small; it mimics it in almost every way.

As an independent scholar I live a life not unlike the Professor's, mutatis mutandis, because I am a woman, and have children, and the times are different; but the mixture of self-imposed isolation and institutionally-imposed exclusion nevertheless has a familiar feel. Even the Professor's microcosmic recreation of the university at home feels familiar. My gamekeeper's cottage is a solid brick bungalow on a small country acreage outside Durham, Ontario, also filled, if not crammed, with books-for unlike the Professor, I do not own a set of Du Cange (indeed I have often wondered where 
the funding for his expensive book collection came from; for though, unlike him, I always have enough to eat, I seldom seem to have enough money to buy all the books I need). I do, however, admire from a distance my Dr Cooks and my masters of Trinity, and likewise dream, perhaps impossibly, of that fellowship of the very lowest class at one of the poorer colleges. Like the Professor, I remain a medievalist because it is not possible for me to be anything else. It might seem that I have only to begin making my own dandelion wine for the parallels to be complete.

Yet there are differences between us of course (or are there? I glance again, not too directly, at the Professor, perching on his mislaid volume of Du Cange). To all intents and purposes, at any rate, the most pertinent difference between us is that, unlike the Professor, I am connected to an international network of scholars and resources through the internet, without which it is no exaggeration to say that I would hardly be able to do my work at all. The internet is a chink in the wall of my isolation, rather a large one, commanding a longer view as the years pass. It links me to colleagues, libraries, and manuscript resources, and even the more enterprising graduate students in my area who have managed to nose my name and address out on the web. I am always pleased when this happens, perhaps in part because I am positioned where I can ignore the less brilliant of them if I choose. So far, however, I have tried to encourage almost all of them, because when I dream of impossible successes I most frequently imagine that someday enough of these young scholars might collect around me to edit a festschrift in my honour (a very small one of course, with an unassuming cover, put out by one of the less prestigious presses, perhäps in Missouri or Florida). I am aware that if this is ever to happen even the dullest of them (indeed perhaps especially the dullest) will need a great deal of encouragement from me.

Like the Professor (whose access to rare books and manuscripts in his tiny cottage may seem magical), my scholarly work, much of which has been of a collaborative nature, has proceeded happily, if a little haphazardly, despite my lack of university affiliation. In this regard it is possible for me to tell a quite different kind of story, a narrative of discovery which has much more the flavour of a success story (for a story of discovery cannot be a story of failure or it would not be a story at all). One of my most exciting current projects is the edition of a fourteenth-century Latin ritual text, the Liber visionum of John of Morigny, which I am working on with Nicholas Watson, who discovered our first copy of this book in the McMaster University Library in 1994. The Liber visionum, which prior to the 1990's was known only from a chronicle 
account (which described its burning in 1323 at the University of Paris as an "heretical and sorcerous" revival of a condemned ritual practice, the Ars notoria), comprises, among other things, a set of seven and thirty prayers to invoke the blessed Virgin, the nine orders of angels, and the Holy Spirit, for the purpose of infusing the operator with a knowledge of the seven liberal arts, philosophy, and theology.

Despite its condemnation, the number of copies of the Liber visionum we know to be extant has been growing steadily over the last nine years. We are now aware of fourteen full and partial copies of this text, mostly of Austrian or north Italian provenance. The location of these manuscripts and their transcription and editing has been facilitated by resources available over the internet (particularly the Hill Monastic Manuscript Library and their online database), the generosity of colleagues who share their findings with us, and the Social Sciences and Humanities Research Council of Canada, from whom we have received generous support. The area opened up by John of Morigny's writing is a fascinating one to have access to; the text itself is unusual, startling, sometimes beautiful, and new manuscripts continue to divulge their secrets. In the opening pages of his book, John tells the story of his experiences at the school of Chartres; he writes that he was too poor to buy books and exemplars and turned to magic for help; he describes the visions he had, both demonic and divine, and his ultimate rejection of magic and subsequent reception of the Book of Thirty Prayers from the virgin Mary. Thus unfolds the tale of a man who seeks and almost manages to attain through prayer and dedication to the Virgin what Jude could not achieve by years of hard work: an institutional place for a self-made brand of knowledge. If John failed in the end to get formal ecclesiastical support for the prayers and rituals prescribed in Book of Visions it is still difficult for me not to cheer the enterprise. Every new copy of his text that falls into my hands is another sign that he was not aloneor that we are not alone, he and I; that there is something of value here, and not only to me.

As noted, the story of work on John of Morigny is essentially a story of success, a story of engagement, discovery and progress at least; and in this way it is profoundly at odds with the story I began with-the Professor's story of isolation, dissociation, and failure. Indeed the two stories hardly even seem to touch one another (except perhaps through the appearance of magic that shadows my ability to reach out through the internet for information on Graz Universitätsbibliothek 680 with the Professor's ability to access Cambridge University Library Ii. 4.26, and ten volumes of Du Cange's Glossarium mediae et infimae latinitatis in his run-down gamekeeper's cottage). In many 
ways, this is the biggest problem I have-the rift, that is, between the types of narratives available to anchor my experience, the way things in these narratives don't seem to mesh or even connect with each other.

I wanted to make a point about the difficult mesh between these two stories because of the problem I initially faced in trying to answer the questions posed by Jane Toswell in her letter of invitation to write something for this issue of Florilegium. Medievalists were being asked to write on "how medieval studies is taught (or if it is taught) where you are, whether the focus is disciplinary or interdisciplinary; how you and your colleagues engage in research in the field; and generally how medievalists in your vicinity accomplish their work." I've tried to answer these questions as best I can with respect to my own work, though of course I've no idea how medievalists in my vicinity accomplish their work. So far as I know there aren't any in Durham, Hanover, or Elmwood. With a few exceptions I am not in close contact with my medieval colleagues at local universities either. I am familiar with the work of a few graduate students who have sought me out from England, Hungary, and North Carolina, but not, at present, with anyone working in Toronto, Kitchener, or London, Ontario. Which brings me back inevitably to the narrative of failure, isolation, and dissociation: I live in Canada; I do research which has been supported by SSHRCC, on a text represented in a manuscript held in a Canadian library; but I remain out of touch with most of the forces that shape the discipline locally. If this doesn't feel quite right, it is only one of many things that don't feel quite right, and hardly the most pressing.

But there is another point to all this, for of course the problems that derive from being caught between conflicting narratives are not mine alone. In fact the Professor's resigned and good-hearted failure, even Jude's less comfortable exclusion from Christminster, involves slightly more anachronism than I have suggested so far; for nowadays some of the Dr Cooks and the masters of Trinity may be feeling less complacent than they used to (or at least less complacent than they are depicted as feeling in these excursuses on academic success and failure written slyly from the margins). In an article in the most recent issue of the MLA publication Profession, James Slevin describes the situation of the universities in dramatic terms: "Colleges and Universities are, in short, undergoing what might be termed economic, cultural, and sometimes overtly political colonisation by larger institutions of various kinds. This process is not monolithic. It is a process that resembles vultures happening on a weakened prey and is in precisely this way purposeful."2 Slevin goes on to describe another apparently conflicting set of narratives supporting the interests of 
administrative and faculty conflicts respectively:

The storyline here seems to be that the reforms undertaken by visionary administrators are blocked by faculty cultures in the thrall of darkness. One could just as easily create a storyline in which visionary faculty members, concerned about "genuine educational reform," are blocked by benighted administrators.... There are two versions to this story, but it's the same story. My point is that neither story gets us anywhere.

Neither story gets us anywhere, because stories are the problem. Pressure for change in these discourses is never demonstrated or even explained but rather elaborated through a millennialist rhetoric by means of which contingent and interested initiatives are simply chronicled as change and naturalised as necessity....

It is hard to talk about the future because the future has been appropriated by anti-intellectual forces (67).

Perhaps the situation Slevin describes is not quite as novel as it seems, for the predatory birds have always been there and the colleges and universities have always been vulnerable to them, more particularly in times of economic instability. It is possible to see exactly the same forces in operation, for example, in the College meeting described with a kind of fierce satiric zest in the first chapter of C.S. Lewis' novel That Hideous Strength, published in 1945 (the narratives of change and necessity chronicled there in the mouths of Curry and Feverstone will have to stand in for the kind of contingent and interested initiatives Dr Cook and the master of Trinity might have had to put up with; for Lewis was more of an insider and understood faculty politics more than a reclusive eccentric like White might have been expected to do).

But Slevin's point is nevertheless taken, for lately the millennialist rhetoric has emerged elsewhere than in the university and has been used to purposes even more destructive; fueled by millennialist rhetoric, one after another, suicide bombers carry their victims with them into the abyss. We see around us the ruins of many things that a short time ago seemed powerful and stable, and if the universities also began to fall apart in some drastic and unpleasant way this would come as something which perhaps was not much of a surprise. Everyone feels a little more apocalyptic than usual; corporations are beginning to seem nearly as vulnerable as universities these days, and the birds of prey are visible in increasing numbers everywhere. In response to these predatory forces Slevin suggests: "We should be concerned primarily not with the future but with clarifying the present and with countering future talk not with 
alternative projections about the possible, predictable, or inevitable but by arguing for what we understand to be the good. Not where we are going but what we stand for" (68). This seems salutary advice.

Above I described the Professor as a little microcosm of the university that has spun off from its dynamic centre and attained an almost completely separate existence. Perhaps at the moments when things seems to be falling apart more than usual-when what the university stands for seems a little less clear at the centre of things-then what exists on the periphery may take on relatively more importance. The Professor, despite (or perhaps because of) his isolation and dissociation, might be seen to hold out some kind of hope for the survival of the University itself, or more precisely, for the survival of what the university stands for: for its goou, manifested in a way that has been put beyond the contingent and interested initiatives. The independent scholar who pursues a vocation of scholarsh ip outside the university, carrying on research and writing only for the sake of discovery and because it is work that someone must do, might be seen to encapsulate the essential values of the university in its most pure form.

I don't mean to suggest that it is easier for the independent scholar to remain above the World, or even to suggest that it would be a good thing if she did. The contingent and interested initiatives exist around and within all of us, within me also; at times they do interfere with the things that facilitate scholarship-my time mainly; but also money and other more intangible kinds of support. At times indeed the worldly and scholarly concerns collide with all the force of ten-ton tractor-trailers on a slippery highway. These collisions may be internally difficult to sustain for many reasons, but they do not really interfere with my basic desire to sift through the manuscript evidence, bring witnesses together, reconstruct little pieces of history - in essence, to find out what bappened. Because of the persistence of this desire, I have never doubted the absolute value of the history I am in the process of piecing together. And my own experience is that one is able to be more profoundly in touch with the absolute value of research and writing when its value as symbolic capital is stripped away.

It is perhaps for this reason, as much as from compassion for the dissociated themselves, that more and more professional organisations have begun reaching out, though still in a manner blindly, to the periphery of the academic world, trying to grasp the unaffiliated, to make a place for them in their membership lists, to open up fora (like this one) for the voices of independent scholars to be heard. We are all a little more marginal than we used to be. The value of learning itself (but perhaps especially the kind that writes "in a twelfth-century hand, in Latin") has been undermined over 
the past two decades by forces both outside and inside the universities. It is hard to predict what will come of this situation in another ten or twenty years, but in the meantime the work of the professional organisations not only in binding together the affiliated and the unaffiliated, but also in clarifying the present and arguing for the good, may well be more important than it has ever been before.

\section{Elmwood, Ontario}

\section{Notes}

1 Originally published by G.P Putnam's Sons in 1946; my quotation taken from the Ace Books edition (New York, 1989), p. 19.

2 James F. Slevin, "Keeping the University Occupied and Out of Trouble," Profession 2002, pp. 64-5. 